\title{
Blanka Brzozowska
}

Uniwersytet Łódzki

\section{Crowdfunding - nowy model finansowania kina? ${ }^{1}$}

\section{Dyskusja wokół crowdfundingu - główne problemy}

W ostatnich latach obserwujemy coraz większy wzrost popularności społecznościowych form finansowania dóbr kultury. Crowdfunding, czyli „finansowanie przez tłum", opiera się na dobrowolnym wkładzie finansowym niezorganizowanej grupy odbiorców na zasadzie darowizny bądź wymiany ${ }^{2}$. Forma ta wywodzi się z działań crowdsourcingowych, których podstawe stanowi dobrowolna, oddolna działalność niezorganizowanej grupy, definiowanej jako „tłum”. Członkowie takiej grupy spontanicznie decyduja się na połączenie wysiłków, najczęściej w celu rozwiązania jakiegoś problemu (np. znalezienia słabych punktów w oprogramowaniu komputerowym $)^{4}$. Istotne jest, że uczestnicy takiego działania nie są w żaden sposób zorganizowani na stałe, ani też nie otrzymuja zapłaty za swoje wysiłki. Nagroda jest najczęściej satysfakcja $\mathrm{z}$ wykonanego zadania oraz wzrost reputacji ( $\mathrm{w}$ danym środowisku, np. programistów), co pozwala na dostrzeganie analogii z działaniami podejmowanymi w ramach gier (wyzwania/questy, możliwość osiagania kolejnych, wyższych poziomów, a co za tym idzie - uznania innych graczy).

Nieco inaczej rzecz się ma w przypadku crowdfundingu, który umożliwia niezrzeszonym członkom „tłumu” wpływanie na dany projekt poprzez niewielki

\footnotetext{
${ }^{1}$ Projekt został sfinansowany ze środków Narodowego Centrum Nauki przyznanych na podstawie decyzji numer DEC-2011/03/D/HS4/03408.

${ }^{2}$ Paul Belleflamme, Thomas Lambert, Armin Schwienbacher, Crowdfunding: Tapping the Right Crowd, Rochester, NY 2013, http://ssrn.com/abstract=1836873 [dostęp: 26.05 2014]; Crowdfunding FAQ / Finansowanie spotecznościowe, crowdsourcing, social lending. http://crowdfunding. pl/crowdfunding-faq/ [dostęp: 26.05.2014].

${ }^{3}$ Zob. http://www.crowdsourcing.com/ [dostęp: 26.05.2014]; Jeff Howe, The Rise of Crowdsourcing, "Wired", 14.06.2006, http://archive.wired.com/wired/archive/ 14.06/crowds.html [dostęp: 26.05.2014].

${ }^{4}$ Zob. Thomas Erickson, Geocentric Crowdsourcing and Smarter Cities: Enabling Urban Intelligence in Cities and Regions, a position paper for the 1st International workshop on ubiquitous crowdsourcing, UbiComp'10, September 26-29, 2010, Copenhagen, Denmark, http://www.crowdsourcing.org/document/ geocentric- crowdsourcing-and-smarter-cities/5678 [dostęp: 26.05.2014].
} 
wkład finansowy. Podstawa zaangażowania nie jest jednak chęć zysku i zwrotu, lecz emocjonalne przywiazanie do tekstu/artysty lub po prostu zainteresowanie prototypem produktu. Henry Jenkins wskazuje w swoich pracach na konieczność dostrzeżenia wpływu kreowanych przez lata, aktywnych form mniej lub bardziej niszowej działalności fanowskiej na współczesne postawy większości konsumentów, co przejawia się między innymi w tendencji do aktywnego współuczestniczenia w tworzeniu produktu/marki oraz domagania się praw do wyrażania własnego zdania na temat wprowadzanych zmian ${ }^{5}$. Można zatem, kontynuujac ten tok myślenia, wskazać, że opisane zaangażowanie emocjonalne wiązać należy z fanowskim rodowodem wszelkich działań z przedrostkiem crowd. W tym wypadku wkładana w crowdsourcing praca (fan labour) zastapiona zostaje niewielkim wkładem finansowym (fan vesting) ${ }^{6}$. Taka podstawa zakłada duże zaangażowanie ze strony odbiorcy, który nie jest zainteresowany finansowym sukcesem projektu, lecz bardziej możliwością osiagnięcia emocjonalnej gratyfikacji. Użytkownicy platform crowdfundingowych decyduja się zatem na niewielki wkład finansowy, w zamian otrzymujac na przykład gadżety związane $\mathrm{z}$ filmem ${ }^{7}$ bądź też $\mathrm{z}$ innym projektem. Materialna nagroda ma charakter jedynie symboliczny (choć można sobie wyobrazić, że dla fana koszulka podpisana przez artystę ma wyjątkowe znaczenie), natomiast najistotniejsza jest możliwość uczestniczenia w procesie twórczym, co zostaje odnotowane - w przypadku filmu, na przykład w napisach końcowych bądź też poprzez nadanie imienia jednej z postaci.

Kwestią wzbudzajaca kontrowersje jest w tym kontekście możliwość i chęć wpływania na tekst, co ściśle łaczy się z przyjętym jako wzorzec charakterem aktywności fanowskiej. Nie chodzi tu jedynie o sprawe praw autorskich (szerzej opisywana w cytowanych wcześniej pracach Henry'ego Jenkinsa), ale również o problem postrzegania pozycji artysty. Pojawiaja się zatem pytania, jak dalece odbiorcy - nawet zdeklarowani jako fani, darzacy dany tekst/twórce silnymi uczuciami - maja prawo ingerować w artystyczna wizję? W tym miejscu uwydatnia się różnica między crowdsourcingiem i crowdfundingiem. W tym pierwszym, o ile istnieje jeden zleceniodawca (może być to np. firma, robiaca w ten sposób badanie rynku lub ewaluację produktu, ale równie dobrze inicjatywa może mieć charakter oddolny), działa on niejako na drugim planie, jego zadanie kończy się wraz ze sformułowaniem problemu, co zresztą wpływa na absolutna nieprzewidywalność tego typu projektu („tłum” może po prostu nie zareagować na zachęty albo też zniechęcić się po jakimś czasie, uznając, że zadanie nie jest już interesujace). W przypadku finansowania

${ }^{5}$ Henry Jenkins, Kultura konwergencji: zderzenie starych i nowych mediów, Warszawa 2010; Henry Jenkins, Sam Ford, Joshua Green, Spreadable Media: Creating Value and Meaning in a Networked Culture, New York 2013.

${ }^{6}$ Patryk Galuszka, Victor Bystrov, The Rise of Fanvestors: A study of a Crowdfunding Community, "First Monday" 2014, Vol. 19, No. 5.

${ }^{7}$ Częstym rozwiązaniem jest możliwość znalezienia się w grupie konsumentów otrzymujących produkt w pierwszej kolejności i w okazyjnej cenie. W przypadku filmu nagrodami są najcześciej koszulki, plakaty z autografami oraz możliwość spotkania/kontaktu z artystą. 
społecznościowego sytuacja wygląda nieco inaczej. Artysta/wykonawca często godzi się na rezygnację z części swojej kontroli nad projektem (co przypomina między innymi crowdsourcingowe praktyki związane $\mathrm{z}$ pisaniem fan fiction), pozwalajac fanwestorom ${ }^{8}$ na ingerencję w proces twórczy. Jednak w wielu wypadkach uczestnictwo „tłumu” sprowadza się do możliwości wyrażenia swojego poparcia i emocjonalnego zaangażowania, co przekłada się na wkład finansowy. Sytuacja ta jest dwuznaczna dla obu stron, co znajduje swój oddźwięk w skrajnie odmiennych opiniach artystów na temat nowej formy finansowania. Z jednej strony, wskazuja oni na zbliżenie do odbiorcy i zwiększenie swobody twórczej poprzez uniezależnienie się od wytwórni (filmowych czy muzycznych - główna propagatorka tego poglądu i prekursorka crowdfundingu jest Amanda Palmer, wokalistka kabaretowo-punkowej grupy Dresden Dolls ${ }^{9}$ ). Z drugiej, niektórzy artyści odbieraja tego typu zwracanie się do publiczności o dofinansowanie jako upokarzajace i w pewien sposób obniżajace status artysty.

Innym problemem z tym związanym jest kwestia znanego nazwiska, które może stać się magnesem dla kampanii crowdfundingowej. Niektórzy twórcy, jak na przykład reżyser Kevin Smith, deklaruja, że nie odwołaja się do tej formy finansowania z powodów etycznych, zakładajac, że celebryta jest w stanie znaleźć źródła finansowania projektu w inny sposób, zaś zwracając się do „tłumu” odbiera te możliwość początkujacym artystom ${ }^{10}$. Walutą crowdfundingu jest jednak emocjonalne zaangażowanie odbiorców ${ }^{11}$, nie zaś jedynie ich uwaga, przyciagnięta, dzięki sprawnie przeprowadzonej promocji. Można powiedzieć więcej, to sam crowdfunding jest promocją i podstawa dystrybucji (o czym więcej w dalszej części artykułu), zmienia zatem kształt relacji artysta/odbiorca i nie może być do niego przykładany wzorzec, którego baza jest tradycyjny model marketingowy. Na niekorzyść krytyki Smitha działają również przypadki projektów nieudanych, które firmowane były przez znane osoby.

Przykładu dostarcza kampania firmowana przez aktorkę Helenę BohnamCarter i jej męża, reżysera Tima Burtona. Para promowała projekt Invisible City $^{12}$, stworzony przez pare artystów, Claudie Moseley i Edwarda Shustera. Pomysł opierał się na zbudowaniu w Regent's Park domków na drzewach, które służyłyby jako miejsca wymiany myśli, oddolnego propagowania sztuki, ale przede wszystkim - budowaniu przestrzeni kontaktu społecznego. Założenia oddania fragmentu przestrzeni miejskiej do dyspozycji mieszkańców wydawały się idealnie spełniać wymogi projektu potencjalnie atrakcyjnego dla „tłumu”. Okazało się jednak, że to właśnie nazwiska Bohnam-Carter i Burtona

${ }^{8}$ Pojęcia tego używam dla podkreślenia emocjonalnego zaangażowania użytkowników. Będzie to miało szczególne znaczenie w dyskusji dotyczącej nowych rodzajów crowdfundingu, majacego przede wszystkim stanowić źródło zysku.

${ }^{9}$ Zob. http://www.ted.com/talks/amanda_palmer_the_art_of_asking [dostęp: 26.05.2014].

${ }^{10}$ Więcej na ten temat: Blanka Brzozowska, Crowdfunding - nowe perspektywy dla produkcji i promocji filmowej, „Kwartalnik Filmowy” 2014, nr 85.

${ }^{11}$ Henry Jenkins posługuje się w tym kontekście terminem „kapitał emocjonalny”.

${ }^{12}$ Zob. http://theinvisiblecity.com/; https://www.kickstarter.com/projects/invisiblecity/the-invisible-city [dostęp: 26.05.2014]. 
zadziałały na niekorzyść projektu, który został odebrany jako elitarny, a wręcz nieuczciwy. Pojawiały się głosy, że twórcy tej rangi (i o tak dużym majątku) moga sobie pozwolić na samodzielne sfinansowanie projektu, jeśli naprawdę chca zrobić coś dla lokalnej wspólnoty. Nie bez znaczenia była również kwota 500000 funtów. W porażce tej ujawniła się cała specyfika crowdfundingu z perspektywy jest „fanowskiego” i wspólnotowego rodowodu; specyfika, która nie wyczerpuje się w kwestiach finansowych. Budowanie „tłumu” opiera się bowiem na działaniach wspólnotowych i to one sa głównym elementem tego typu modelu finansowania. Skoro fanwestorzy oczekuja nie tylko możliwości zainwestowania pieniędzy, lecz także (a raczej - przede wszystkim) emocji, wspólnota nie jest produktem ubocznym, a jej wykreowanie, jest głównym zadaniem udanej kampanii. Nie może ona zatem koncentrować się na kwestiach finansowych, choć są one nadzwyczaj istotne, to bowiem wzbudza podejrzliwość, a wręcz niechęć potencjalnych fanwestorów. Wysoka, spodziewana przez autorów kampanii Invisible City suma pieniędzy nie tyle przerastała wyobraźnię wspólnoty, ile raczej budziła podejrzenia co do charakteru projektu, który odebrany został jako w pewien sposób sztuczny, narzucony przez „elitę”. Należy w tym miejscu stwierdzić, że niewielkie stosunkowo kwoty wpłacane przez fanwestorów składają się, co prawda, na niekiedy całkiem spore budżety filmowe (najczęściej przywoływanym przykładem jest film Veronica Mars, którego kampania osiagnęła sumę 5702153 dolarów ${ }^{13}$ ), lecz w tym przypadku podkreślano, że reżysersko-aktorski duet, ze względu na swój status, nie musiał odwoływać się do crowdfundingu (jak to miało miejsce w przypadku filmu Veronica Mars, którego produkcję wytwórnia uznała za nieopłacalną i tylko dzięki wsparciu fanów realizacja filmu doszła do skutku).

Przytoczony przykład nie tylko podkreśla rolę fanowskiego i wspólnotowego rodowodu crowdfundingu, lecz także prowadzi do kolejnego problemu, jakim jest zmiana prawodawstwa, a co za tym idzie - sposobu myślenia o nowej formie finansowania. Jak już zostało powiedziane, jeśli chodzi o ich skalę, projekty crowdfundingowe najczęściej można określić jako niewielkie bądź średnie $^{14}$. Obecnie jednak wiele dyskutuje się na temat możliwości finansowania za pomoca modelu społecznościowego większych projektów, np. w przestrzeni miejskiej. Problem ten w interesujący sposób dotyka przemysłu filmowego. Jak pokazałam w innym miejscu ${ }^{15}$, crowdfunding filmowy odnosi duże sukcesy, czego symbolem stały się, z jednej strony, uznanie środowiska (nagrody na festiwalu Sundance, nagroda Oscara), z drugiej natomiast, uznanie szerokiej publiczności, obiecujące komercyjny sukces (spektakularna kampania filmu Veronica Mars, która jak do tej pory osiagnęła liczbę 91585 wspierajaccych).

Sytuacja ta skłania do namysłu nad perspektywami dalszego rozwoju nowej formy finansowania. Kontekstu dla tych rozważań dostarcza toczaca się w Stanach Zjednoczonych dyskusja nad tzw. JOBS Act (Jumpstart Our Business

${ }^{13}$ Więcej na ten temat: B. Brzozowska, op. cit.

${ }^{14}$ Andrea Ordanini et al., Crowd-funding: Transforming Customers into Investors Through Innovative Service Platforms, “Journal of Service Management” 2011, Vol. 22, No. 4.

${ }^{15}$ B. Brzozowska, op. cit. 
Startups Act), którego najistotniejsze ustalenia regulować mają między innymi działanie podmiotów finansowanych poprzez finansowanie społecznościowe - podobnie jak w Polsce ${ }^{16}$ - prawna sytuacja tego typu działalności jest niejasna ${ }^{17}$, zaś tzw. equity crowdfunding, w którym inwestujacy stają się udziałowcami $\mathrm{w}$ zyskach, jest nielegalny ${ }^{18}$. Założeniem dokumentu jest umożliwienie firmom rozpoczynającym działalność korzystanie z nowych form finansowania poprzez zniesienie istniejacych dotychczas ograniczeń prawnych (m.in. dotyczacych udziału w zyskach, maksymalnych limitów finansowych w zbieranych sumach, limitów inwestycji czy regułach rejestrowania tego typu działalności) ${ }^{19}$. Ustawodawcy deklaruja konieczność takich zmian w obliczu kryzysu ekonomicznego (tworzenie nowych miejsc pracy) oraz wobec nieuregulowanej sytuacji nowych form finansowania. Kontrowersje wywołuje jednak stopień ochrony inwestorów w nowym modelu. Pomimo zapewnień i starań SEC (U.S. Securities and Exchange Commission) ${ }^{20}$, narastają kontrowersje i wątpliwości wokół nowych regulacji ${ }^{21}$, krytycyzm w tej sprawie wyrażaja jednak przede wszystkim organizacje konsumenckie zrzeszone wokół Consumer Federation of America ${ }^{22}$. W zamieszczonych na jej stronie listach skierowanych do członków Kongresu, wyrażone zostaja obawy dotyczące niedostatecznego uwzględnienia w pracach nad ustawą możliwości oszustw finansowych, które potencjalnie dotykać będą drobnych inwestorów ${ }^{23}$. Skandal związany z Enronem i jemu podobne wciąż pozostają żywe w pamięci opinii publicznej, podnoszą się również głosy krytyki wobec artystów korzystających $\mathrm{z}$ crowdfundingu ${ }^{24}$ i wobec samych platform ${ }^{25}$.

${ }^{16}$ Jeśli chodzi o sytuację crowdfundingu w Polsce, najistotniejsze było uchylenie obowiąującej do tej pory ustawy o zbiórkach publicznych z roku 1933. Zwłaszcza istotny jest fragment ustawy, który mówi o tym, że jej zakresem nie są objęte wpłaty za pośrednictwem esemesów, Internetu i wpłat na konto bankowe, http:// crowdfunding.pl/2014/04/01/nowa-ustawa-o-zbiorkach-publicznych-podpisana/ [dostęp 26.05.2014].

Efektem nowych ustaleń jest definicja, wedle której „Zbiórki publiczne to nie crowdfunding, mimo pewnych podobieństw w przebiegu procesu pozyskiwania finansowania”. Oznacza to inny tryb postępowania i brak konieczności starania się o zgodę na przeprowadzanie zbiórki w przypadku finansowania społecznościowego; http://crowdfunding.pl/2014/04/23/maic-rozpoczyna-konsultacje-dot-finansowania-spolecznosciowego/ [dostęp: 26.05.2014].

${ }_{17}$ J. J. Calao, Breaking Down The JOBS Act: Inside The Bill That Would Transform American Business, http://www.forbes.com/sites/jjcolao/2012/03/21/jobs-act/ [dostęp: 26.05.2014].

${ }^{18}$ Dyskusja na ten temat toczy się również w Polsce. Zob. http://crowdfunding.pl/2014/05/16/ gielda-papierow-wartosciowych-a-crowdfunding/ [dostęp: 26.05.2014].

${ }^{19} \mathrm{http}$ ://www.sec.gov/News/Testimony/Detail/Testimony/1365171515996\#.U3nDlqZ1OR8 [dostęp: 26.05.2014].

${ }^{20} \mathrm{http}$ ///www.sec.gov/News/PressRelease/Detail/PressRelease/1370539707782\#.U3nKj6Z1PFa.

${ }^{21}$ David S. Hilzenrath, Jobs Act could remove investor protections, SEC chair Mary Schapiro warns, "The Washington Post" 2012, http://www.washingtonpost.com/business/economy/jobs-actcould-open-a-door-to-investment-fraud-sec-chief-says/2012/03/14/gIQA1vx1BS_story.html.

${ }^{22}$ Dokładna lista dostepna pod adresem: http://www.consumerfed.org/news/473 [dostep: 26.05.2014].

${ }^{23}$ Zob. http://www.consumerfed.org/news/467 [dostęp: 26.05.2014].

${ }^{24}$ D. J. Walkin, Rockers Playing for Beer: Fair Play?, http://artsbeat.blogs.nytimes. com/2012/09/12/ rockers-playing-for-beer-fair-play/.

${ }^{25}$ Noreen Malone, The False Promise of Kickstarter, http://www.newrepublic.com/article/politics/ magazine/ 110225/the-false-promise-kickstarter [dostęp: 26.05.2014]. 
Według danych zebranych przez Ethana R. Mollicka z Pennsylvania Universi$\mathrm{ty}^{26}$, ponad $75 \%$ zakończonych sukcesem kampanii nie spełnia swoich obietnic wobec użytkowników inwestujących w projekty (chodzi tu głównie o spóźnienia w dostarczaniu obiecanych gadżetów/produktów). Łącząc to z optymizmem, jaki towarzyszy w ostatnich latach rozwojowi finansowania społecznościowego dóbr kultury (w tym filmu), należy przyznać amerykańskiemu badaczowi rację, że mamy do czynienia ze zjawiskiem zupełnie jeszcze nie rozpoznanym przez świat akademicki. Mollick, starając się wypełnić tę lukę, zwraca w swoim badaniu uwage na najistotniejsze czynniki, decydujące u sukcesie lub też porażce crowdfundingu oraz na związane z nim zagrożenia. Co ciekawe, autor w podsumowaniu swojego artykułu podkreśla stosunkowo niski współczynnik oszustw dokonywanych na platformie Kickstarter, na co wpływ maja specyfika nawiazzwanych tu relacji oraz zakres i sposób dostarczania informacji. Chodzi tu przede wszystkim o aktywny charakter działalności wspólnoty, która w szybki sposób jest w stanie przekazywać wiadomości na temat ewentualnych nadużyć, jak również o stałość i bliskość kontaktu pomiędzy fundatorami a autorem projektu oraz konieczność zawierania w opisie szczegółowych danych na temat autora oraz produktu ${ }^{27}$. Rzecz jasna nie eliminuje to możliwości podejmowania prób oszustwa, a wprowadzenie nowych regulacji prawnych rozszerzających obszar działania crowdfundingu z pewnością zwiększy ryzyko. Należy jednak podkreślić, iż na tym etapie rozwoju samej formy i wprowadzania regulacji prawnych jej dotyczących nie jesteśmy w stanie przewidzieć, w jakim stopniu wskazane przez Mollicka zagrożenie może zagrozić fanwestorom. Z pewnością natomiast, zwłaszcza z perspektywy badania produkcji filmowej, ważne jest zwrócenie uwagi na fakt, że kampanie dotyczące różnych dóbr wykazują również zróżnicowanie pod względem poziomu ryzyka, stopnia zaangażowania, charakteru inwestycji i specyfiki osób zaangażowanych w nie. Wynika z tego, iż należy się w szczególny sposób przyglądać społecznościowemu finansowaniu filmu, biorąc pod uwage szczególną rolę twórcy oraz widza, który może być postrzegany jako fanwestor, jest zatem kimś innym, niż udziałowiec.

Warto podkreślić, że sami przedstawiciele platformy Kickstarter deklaruja niechęć do przyjęcia formy equity crowdfunding. Współzałożyciel i członek zarządu firmy, Yancey Strickler, potwierdził w jednym z ostatnich wywiadów ${ }^{28}$, że umożliwione przez nowe regulacje prawne (tzn. Jobs Act) stworzenie możliwości realnego zarabiania na udziałach w zyskach, stanowi zaprzeczenie idei, która legła u podstaw założenia firmy. Kickstarter służyć ma rozwijaniu projektów, które cechować ma kreatywność, lecz nie oznacza to koniecznie zwrotu finansowego. Strickler stwierdza górnolotnie, iż „są rzeczy ważniejsze od pieniędzy”, mając na myśli właśnie wspólnotowy i w pewien sposób „fanowski” charakter działania crowdfundingu w wydaniu Kickstartera. Warto przy okazji dodać,

${ }^{26}$ Ethan Mollick, The dynamics of crowdfunding: An exploratory study, "Journal of Business Venturing" 2014, Vol. 29, No. 1.

${ }^{27}$ Ibidem, s. 15.

${ }^{28}$ Natasha Lomas, "There Are Things That Are More Important Than Money," Says Kickstarter CEO, http://techcrunch.com/2014/05/05/yancey-strickler-disrupt-ny/ [dostęp: 26.05.2014]. 
że platforma ta wyjątkowo dużo uwagi poświęca projektom filmowym - między innymi organizując własny festiwal filmowy oraz aktywnie biorac udział w promocji zrealizowanych filmów ${ }^{29}$. Skłania to do przyjrzenia się nowej formie z perspektywy obu stron i zastanowienia się, czy i jak nowe regulacje prawne oraz sukcesy kampanii takich jak Veronica Mars wpłyną na ich relacje.

\section{Artyści czy menadżerowie?}

Problem pozycji artysty w nowym modelu finansowania wydaje sie jednym z najistotniejszych dla dalszego rozwoju crowdfundingu filmowego. Dobrego przykładu dostarcza tekst napisany dla „Hollywood Reporter” przez producenta oscarowego filmu Little Miss Sunshine, Davida T. Friendly ${ }^{30}$. W krótkim artykule przedstawia on perypetie związane z pierwsza prowadzona przez siebie kampania crowdfundingowa na rzecz dokumentalnego filmu Sneakerheadz, którego tematem jest zjawisko kolekcjonowania butów tenisowych (kicks). Friendly przedstawia najpierw dylematy zwiazane z wyborem platformy, wskazując na takie elementy jak: możliwość wypłaty zebranej sumy, o ile nie uzyskała ona minimalnej zakładanej granicy, procent pobierany przez platformę i wreszcie, możliwość otrzymania pomocy merytorycznej przy technicznej obróbce kampanii na platformie. Platforma Kickstarter nie oferuje pierwszego i trzeciego, co powoduje zwiększenie ryzyka, ale przede wszystkim składa całą odpowiedzialność za kampanię - również na poziomie technicznej obsługi strony (uploading treści). Po przeanalizowaniu wszystkich powyższych czynników, Friendly zdecydował się na platformę Indiegogo. Na tym jednak nie kończy się problem kompetencji. Kampania crowdfundingowa nie istnieje bowiem w próżni i nie jest też samowystarczalna na poziomie informacyjnym. Projekty tego typu sa silnie sprzęgnięte z mediami społecznościowymi i tylko dzięki ich właściwemu wykorzystaniu mają szanse na sukces - ilość promowanych projektów jest tak duża, że nietrudno jest przepaść bez odzewu. Konkretna kapania musi zostać odpowiednio zdefiniowana i zaktywizowana za pomoca słów kluczowych (określa się to terminem boost), co pozwoli na jej częstsze wyświetlanie w wynikach wyszukiwania, ale również musi zostać obudowana strefa aktywnej, dwustronnej komunikacji z potencjalnie zainteresowanymi odbiorcami. Wszystko to przyczynić się ma do zwiększenia ruchu na stronie kampanii (boost traffic). Satysfakcjonujace poprowadzenie tego typu projektu wymaga zatem nie tylko dużego wysiłku oraz nakładów czasowych, ale przede wszystkim kompetencji w zakresie posługiwania się mediami społecznościowymi, bądź też zatrudnienia dodatkowej osoby, odpowiedzialnej za tę sferę kampanii. W przypadku „Sneakerheadz” wybrano drugie rozwiązanie,

${ }^{29}$ Zob. https://www.kickstarter.com/watch [dostęp: 26.05.2014].

${ }^{30}$ David T. Friendly, "Little Miss Sunshine" Producer: What They Don't Tell You About Crowdfunding (Guest Column), http://www.hollywoodreporter.com/news/little-miss-sunshine-producer-what-653251 [dostęp: 26.05.2014]. 
co naturalnie przyczyniło się do wygenerowania nowych kosztów (do ich zwiększenia przyczyniła się również konieczność nakręcenia specjalnego teasera, który odpowiadałby potrzebom kampanii prowadzonej w takiej formie).

Warto zatrzymać się na tym zagadnieniu. Friendly w swoim artykule przywołuje tzw. gogofactor, innymi słowy algorytm, który rejestruje cała aktywność użytkownika Indiegogo. Twórcy tej platformy deklarują na swoim blogu chęć zapewnienia autorom absolutnej wolności, co oznacza brak selekcji projektów, ale również konieczność brania odpowiedzialności za całkowita aktywność na stronie swojego projektu. Zatem wszyscy maja równe szanse, jednak to gogofactor decyduje o tym, w jakim stopniu dana kampania będzie promowana przez Indiegogo. Uzyskanie wysokiego wyniku umożliwia umieszczenie kampanii na głównej stronie, w newsletterach i wiadomościach wysyłanych przez Indiegogo do portali społecznościowych. Pamiętać jednak należy, że ów wysoki wynik uzależniony jest także od aktywności innych autorów, zatem oprócz dbania o własną aktywność na stronie, autor powinien śledzić konkurentów ${ }^{31}$.

W nowym modelu artysta musi być jednocześnie zatem biznesmenem i menadżerem. Jak widzi to niezależna dokumentalistka Heidi Ewing (Jesus Camp, Baraka Boys), filmowcy musza zmienić nastawienie i wziaćc odpowiedzialność za swoje projekty ${ }^{32}$. Konieczność przemyślenia strategii promocji nie oznacza „sprzedawania się”, a jedynie zrozumienie, że sztuka posiada aspekt „biznesowy”. Jego zaakceptowanie nie wyklucza swobody twórczej w nowym modelu, w którym artysta sprawuje kontrolę nad dziełem wraz z kolejnymi etapami jego wprowadzania do obiegu, ale jednocześnie niejako oddaje część władzy odbiorcom, zwracając się w pierwszej kolejności do nich.

Dokonująca się zmiana ma charakter bardziej świadomościowy niż technologiczny i stwarza nowy podział wśród twórców z obszaru kina indie. Brian Newman widzi linię tego podziału w zrozumieniu specyfiki realnej zmiany, jaka wnoszą technologie cyfrowe. Jego zdaniem grupa, która nazwać można old school indies (choć przynależność do niej nie jest zależna od wieku, a raczej od postawy w stosunku do omawianych problemów), wykorzystuje technologie cyfrowe w samym procesie tworzenia filmu, nie dostrzegając, że największe możliwości w rozwoju niezależnej twórczości kryją się w nowym modelu dystrybucji i kontaktu z widzem. Dzięki temu filmy tego typu mogą docierać do znaczniej większej widowni, nie tracąc nic ze swego „niezależnego” charakteru ${ }^{33}$.

Jeden z przedstawicieli Kickstartera, Justin Kazmarek, wskazuje główne nieporozumienia dotyczace jego firmy. Problem leży, jego zdaniem, w tym, że Kickstarter nie jest sklepem, choć ludzie zawsze szukają znanych analogii dla rzeczy nowych i staraja się odnaleźć podobne zasady działania, co w tym przypadku kończy się rozczarowaniem. Dla platformy tego typu bardziej przydatne

${ }^{31}$ K.at Popiel, The gogofactor \& How to Get Featured on Our Homepage, https://blog.indiegogo.com/ 2011/08/the-magic-gogofactor.html [dostęp: 26.05.2014].

${ }^{32}$ Kim Voynar, Digital Distribution Revolution, "Movie City News", http://moviecitynews. com/2012/05/ digital-distribution-revolution/ [dostęp: 26.05.2014].

${ }^{33}$ Brian Newman, Posts I Like: "Disrupted: Indie Filmmakers", http://networkedblogs.com/ yeA6l [dostęp: 26.05.2014]. 
jest porównanie do hybrydy mecenatu i tradycyjnej sprzedaży. Crowdfunding stwarza nowa ramę dla twórczości, umożliwiając wspólne działanie artysty i odbiorców. Oczywiście projekty posiadaja swoją wartość, jednak dla wspierajacych kampanię wiążą się to nie tyle z gratyfikacją materialna, co z doświadczeniem uczestniczenia w procesie tworzenia ${ }^{34}$.

Rzecz jasna stwarza to dla filmoznawstwa konieczność nie tylko podjęcia na nowo dyskusji na kwestia autorstwa w kinie (co jeszcze wyraźniej dotyczy projektów crowdsourcingowych ${ }^{35}$ ), ale również zbadania specyfiki nowego widza - fanwestora. Warto również przyjrzeć się problemowi od strony dystrybucji, bowiem, jak już zostało powiedziane wcześniej, w crowdfundingu nie chodzi jedynie o wyprodukowanie filmu, ale raczej o zbudowanie wspólnoty-widowni, zanim on w ogóle powstanie.

\section{Dystrybucja i promocja}

Problemy z dystrybucją filmów niezależnych, sprawiają, że to właśnie one stają się głównymi kandydatami do wypróbowania nowych rozwiązań. Przykładem tego jest kultowa TROMA, która odwołała się do crowdfundingu najpierw wspomagając budżet filmu Return to Nuke ' $\mathrm{Em} \mathrm{High}{ }^{36}$ (2012), potem finansujacc akcję Occupy Cannes! (2013). To drugie było w istocie akcja promocyjna, której celem było zaprezentowanie problemu kina niezależnego na jednym z największych festiwali filmowych świata. Kampania pokrywać miała koszty wyjazdu i prezentacji oraz realizacji dokumentu na temat całej akcji ${ }^{37}$. W swoich wypowiedziach szef wytwórni TROMA, Lloyd Kaufman, podkreśla, że crowdfunding nie może stanowić sposobu na pełne finansowanie filmów (nawet o tak stosunkowo niskim budżecie), może natomiast być wykorzystywany jako narzędzie marketingowe, wspomagające tradycyjne formy promocji filmu. Jednocześnie służyć może badaniu potencjalnego rynku poprzez sondowanie sympatii odbiorców skłonnych do zainwestowania w kampanię crowdfundingowa.

Crowdfunding może być zatem wykorzystany jako uzupełnianie budżetu bądź też finansowanie etapu dystrybucji. Tak stało się w przypadku filmu Detropia Rachel Grady i Heidi Ewing. Film jest artystycznym dokumentem przedstawiajacym miasto Detroit, zaprezentowanym po raz pierwszy na festiwalu Sundance. Pozytywne reakcje publiczności festiwalowej nie pomogły

${ }^{34}$ Suw Charman-Anderson, Kickstarter: Dream Maker Or Promise Breaker?, ttp://www.forbes. com/sites/ suwcharmananderson/2012/11/30/kickstarter-dream-maker-or-promise-breaker/ [dostep: 26.05.2014].

${ }^{35}$ Przykładem jest chociażby aplikacja na telefon, która umożliwia tworzenie crowdsourcingowej ekipy filmowej: http://www.crowdsourcing.org/article/app-turns-smartphone-owners-into-film-crew-members/29510, [dostęp: 26.05.2014]. Popularność zyskuja też projekty montowane z materiałów realizowanych przez fanów: http://magazine.good.is/articles/crowd-crafted-a-musicvideo-by-2-601-contributors1 [dostęp: 26.05.2014].

${ }^{36}$ Konkretnie chodziło o dofinansowanie zatrudnienia na planie profesjonalnie szkolonej kaczki. Troma zebrała na ten cel $\$ 10,192$, przy czym zakładana kwota minimalna wynosiła $\$ 4,000$.

${ }^{37}$ Więcej na ten temat: B. Brzozowska, op. cit. 
jednak autorkom w znalezieniu partnerów do dalszej dystrybucji filmu, co skłoniło je do zwrócenia się ku platformie Kickstarter ${ }^{38}$. Kampania zakończyła się sukcesem, osiągając 71262 dolarów z założonych 60 000. Suma ta pozwoliła autorkom na rozpoczęcie dystrybucji, której zasięg jest zwiększany w miarę zbierania kolejnych funduszy już poza crowdfundingiem.

Innego przykładu dostarcza aktor Matthew Lillard ze swoim reżyserskim debiutem Fat Kid Rules the World ${ }^{39}$. Zdaniem autora, fabuła filmu (historia cierpiącego na otyłość nastolatka, który „zajada” żal po stracie matki oraz jego przyjaciela, bezdomnego narkomana) pozbawiona jest atrakcji, jakie mogłyby przyciagnać dystrybutorów typowego kina dla nastolatków (takich jak sprośny humor, przemoc czy nagość - sam Lillard znany jest między innymi z filmu Krzyk Wesa Cravena), zatem film z założenia musi trafić do publiczności niszowej. Taka publiczność oferuje crowdfunding poprzez zwracanie się bezpośrednio do zainteresowanego odbiorcy i budowanie wspólnoty wokół filmu. Lillard również osiagnął swój cel, uzyskując na dystrybucję fundusz 15800 dolarów na 15000 założonych jako kwota minimalna.

W takim układzie platforma crowdfundingowa w rodzaju Kickstartera pełni funkcje marketingowa i pozwala na „wystartowanie” promocji filmu oraz zbudowanie wokół niego wspólnoty odbiorców, dodajmy, potencjalnie chętnych zainwestować w kolejne projekty. Nie chodzi tu zatem o pełna rezygnacje z funkcji, jakie do tej pory pełniła wytwórnia, lecz o zbudowanie sieci relacji z odbiorcami (oraz innymi artystami), która określić można mianem wspólnoty marki (w tym wypadku owa marka jest nazwisko artysty). Heidi Ewing postrzega ową nową wspólnotę nie tylko jako składająca się z fanów, ale również innych artystów. Reżyserka podkreśla, że to właśnie artyści najlepiej rozumieja dylematy innych artystów, a zatem to oni powinni angażować się we wspieranie innych projektów ${ }^{40}$. Przywołane wcześniej badania Mollicka, ale również badania w ramach grantu „Produkcja partnerska dóbr kultury w modelu finansowania społecznościciowego" ${ }^{41}$, pokazuja, że znaczny udział w kampaniach crowdfundingowych maja przyjaciele i rodzina artystów. Stanowia oni często konieczna bazę dla dalszego rozwoju wspólnoty-widowni, choć może oczywiście się zdarzyć, że sponsorami małych projektów sa głównie znajomi i osoby bezpośrednio zainteresowane (np. lokalna wspólnota, w przypadku projektów miejskich). Tak czy inaczej, można zaryzykować stwierdzenie, że o ile w wielu przypadkach crowdfunding filmowy nie jest w stanie w pełni zastapić działania wytwórni i pokryć całego budżetu filmowego, to z pewnościa dobrze sprawdza się jako element wspomagający dystrybucję i promocje, co jest szczególnie ważne w przypadku kina spod znaku indie.

${ }^{38}$ DETROPIA - We're Releasing our Doc Independently, https://www.kickstarter.com/ projects/detro-piathefilm/detropia-were-releasing-our-doc-independently [dostęp: 26.05 2014].

${ }^{39}$ FAT KID RULES THE WORLD, https://www.kickstarter.com/projects/1499648032/fat-kid-rules-the-world-0 [dostęp: 26.05.2014].

${ }^{40} \mathrm{~K}$. Voynar, op. cit.

${ }^{41}$ P. Gałuszka, B. Brzozowska, projekt finansowany przez Narodowe Centrum Nauki, DEC$-2011 / 03 / \mathrm{D} / \mathrm{HS} 4 / 03408$. 


\section{Podsumowanie}

Crowdfunding, również ten związany z filmem, wywołuje wiele dyskusji i jest zjawiskiem na tyle nowym, nieopisanym i nieuregulowanym prawnie, że trudno w tej chwili przewidzieć konsekwencje i kierunek jego rozwoju. Niniejszy artykuł stanowi próbę zasygnalizowania najistotniejszych kwestii, ze szczególnym wskazaniem na reinterpretację relacji pomiędzy twórca a widzami. Nowe możliwości, jakie niesie ze soba model finansowania społecznościowego, niejako w sposób naturalny przyjmowane sa przez twórców tzw. kina niezależnego oraz kina, które określić można mianem kultowego (czego przykładem jest chociażby Troma). Tłumaczyć to można tradycyjnie mniejszym dystansem pomiędzy fanami tego typu kina a jego twórcami. Crowdfunding jest w takiej sytuacji rozwinięciem tradycyjnych, silnie nacechowanych emocjonalnie praktyk fanowskich, których nowa forma sa „tłumy” fanwestorów.

Problem zdobywania publiczności, a co za tym idzie, konieczności wzięcia pod uwage społecznościowego kontekstu jej funkcjonowania, nie dotyczy jedynie artystów utożsamiajacych się z nurtem indie lub kinem kultu. Henry Jenkins przytacza wypowiedź producentki serialu Ghost Whisperer, Kim Moses, która stwierdza, iż współcześnie nie wystarczy wyprodukować serial telewizyjny, ale trzeba również zatroszczyć się o wykreowanie jego publiczności. ${ }^{42}$ To z kolei wymaga innego, większego zaangażowania producentów, którzy śledza aktywność fanów i podsycaja ich chęć do działania, stwarzając otwarte przestrzenie i przejścia, dzięki którym widzowie moga choć w najmniejszym stopniu poczuć, że sa częścią filmowego świata, a nie tylko jego biernymi obserwatorami. Crowdfunding daje szanse budowania takiej przestrzeni, oddajac w ręce twórców i odbiorców narzędzia, dzięki którym maja szansę stworzyć zupełnie nowa jakość kina.

\section{Bibliografia}

Belleflamme P., Lambert T., Schwienbacher, A., Crowdfunding: Tapping the Right Crowd Crowdfunding: Tapping the Right Crowd, Rochester, NY 2013.

Brzozowska B., Crowdfunding - nowe perspektywy dla produkcji i promocji filmowej, „Kwartalnik Filmowy" 2014, $\mathrm{nr} 85$.

Calao J. J., Breaking Down The JOBS Act: Inside The Bill That Would Transform American Business, http://www.forbes.com/sites/jjcolao/2012/03/21/jobs-act/.

Charman-Anderson S., Kickstarter: Dream Maker Or Promise Breaker?, http://www.forbes.com/ sites/ suwcharmananderson/2012/11/30/kickstarter-dream-maker-or-promise-breaker/.

Erickson T., Geocentric Crowdsourcing and Smarter Cities: Enabling Urban Intelligence in Cities and Regions, a position paper for the 1st International workshop on ubiquitous crowdsourcing, UbiComp'10, September 26-29, 2010, Copenhagen, Denmark, http://www.crowdsourcing.org/document/geocentric-crowdsourcing-and-smarter-cities/5678.

${ }^{42}$ H. Jenkins, S. Ford et al., op. cit., s. 138. 
Friendly D. T., „Little Miss Sunshine” Producer: What They Don't Tell You About Crowdfunding (Guest Column), http://www.hollywoodreporter.com/news/little-miss-sunshine-producer-what-653251.

Galuszka P., Bystrov V., The rise of fanvestors: A study of a crowdfunding community, "First Monday" 2014, Vol. 19, No. 5.

Hilzenrath D. S., Jobs Act could remove investor protections, SEC chair Mary Schapiro warns, "The Washington Post" 2012, http://www.washingtonpost.com/business/economy/jobs-actcould-open-a-door-to-investment-fraud-sec-chief-says/2012/03/14/gIQA1vx1BS_story.html.

Howe J., The Rise of Crowdsourcing, "Wired", 14.06.2006, http://archive.wired.com/wired/archive/14.06/ crowds.html

Jenkins H., Ford S. et al., Spreadable Media: Creating Value and Meaning in a Networked Culture, New York University Press, New York 2013.

Jenkins H., Kultura konwergencji: zderzenie starych i nowych mediów, Warszawa 2010.

Lomas N., "There Are Things That Are More Important Than Money," Says Kickstarter CEO, http://techcrunch.com/2014/05/05/yancey-strickler-disrupt-ny/.

Malone N., The False Promise of Kickstarter, http://www.newrepublic.com/article/politics/magazine/110225/ the-false-promise-kickstarter.

Mollick E., The dynamics of crowdfunding: An exploratory study, "Journal of Business Venturing" 2014, Vol. 29, No. 1.

Newman B., Posts I Like: "Disrupted: Indie Filmmakers", http://networkedblogs.com/yeA6l.

Ordanini A., Miceli L. et al., Crowd-funding: transforming customers into investors through innovative service platforms, "Journal of Service Management" 2011, Vol. 22, No. 4.

Popiel K., The gogofactor \& How to Get Featured on Our Homepage, https://blog.indiegogo. com/2011/08/the-magic-gogofactor.html.

Voynar K., Digital Distribution Revolution, “Movie City News”, http://moviecitynews.com/2012/05/ digital-distribution-revolution/.

Walkin D. J., Rockers Playing for Beer: Fair Play?, http://artsbeat.blogs.nytimes.com/2012/09/12/ rockers-playing-for-beer-fair-play/. 